\title{
Effect of ovariectomy on tonic gonadotrophin secretion in cyclic and post-partum dairy cows
}

\author{
E. Schallenberger and A. J. Peterson* \\ Institut für Physiologie, Südd. Versuchs- und Forschungsanstalt für Milchwirtschaft, \\ Technische Universität München, 8050 Freising-Weihenstephan, West Germany
}

\begin{abstract}
Summary. Blood collections were taken every 20 min over $12 \mathrm{~h}$ on 6 occasions within 1 month before and after gonadectomy of 5 cyclic and 5 post-partum dairy cows and again on one occasion 3-5 months thereafter. By 4 days after ovariectomy of the cyclic cows (i.e. 4 days after oestrus) average plasma $\mathrm{LH}$ values and the frequency and amplitude of pulsatile $\mathrm{LH}$ release had increased about 3 -fold. In the cows ovariectomized 4 days after parturition, mean concentrations of LH, pulse frequency and amplitude rose only about 2 -fold during the initial 4 days. Mean LH values were significantly lower than those of cyclic cows during the first 11 days after ovariectomy. The changes in FSH concentrations were similar to those of $\mathrm{LH}$ in the two groups of cows, with mean values rising about 2 -fold within the first 4 days and the same frequency of pulsatile release, but the amplitude was reduced. By 3-5 months after gonadectomy, the frequency of pulsatile release in both groups of cows had decreased whereas the amplitude had increased, resulting in additionally enhanced average gonadotrophin concentrations.

These findings indicate that the hypothalamo-pituitary axis of parturient dairy cows is partly refractory within the first 15 days after calving and that there is a slower acceleration of pulsatile GnRH release in cows after parturition.
\end{abstract}

\section{Introduction}

Evidence is accumulating that the failure of the suckling beef cow to reproduce post partum as early as the milked dairy cow (King, Hurnik \& Robertson, 1976; Webb, Lamming, Haynes, Hafs \& Manns, 1977) is due, at least in part, to an effect of suckling upon the hypothalamus leading to a diminished release of $\mathrm{LH}$ from the pituitary gland. Thus suckling depresses the basal concentrations of LH in the peripheral circulation (Radford, Nancarrow \& Mattner, 1978; Webb, Lamming, Haynes \& Foxcroft, 1980) as well as the frequency and amplitude of episodic release (Carruthers \& Hafs, 1980) by reducing the GnRH-mediated synthesis and release of $\mathrm{LH}$ from the pituitary (Walters, Kaltenbach, Dunn \& Short, 1981a; Walters et al., 1981b; Smith et al., 1981).

The pituitary of milked and suckling post-partum cows responds to GnRH administration within 10-13 days of calving (Webb et al., 1977; Schallenberger, Schams \& Zottmeier, 1978), which indicates that this gland, given the appropriate stimuli, functions normally and is further evidence that the hypothalamus of the parturient cow is refractory. If this is so then ovariectomy of the post-partum cow should not cause the immediate rise in peripheral gonadotrophin concentrations that occurs in cyclic individuals. The present paper examined the effects of ovariectomy in cows.

* Present address: MAF Research Division, Ruakura Animal Research Centre, Hamilton, New Zealand. 


\section{Materials and Methods}

Experimental animals. Five normally cyclic and 5 post-partum dairy cows of the local Brown Swiss and Simmental breeds (aged 3-9 years) were used. They were tethered indoors, fed twice daily with hay, a mixture of grass and corn silage, and energy supplement and had access to water ad libitum. The post-partum cows were allowed to suckle at least 2 calves twice daily; the regularly cyclic animals, which were milked daily, were 7-12 months from their last parturition and had exhibited 6-10 oestrous cycles.

Ovariectomy. The cows were ovariectomized 4 days after oestrus or calving through a flank incision using a tranquillizer (Combelene: Bayer) and local and extradural anaesthesia (Neocaine 2\%, WDT).

Blood sampling. Samples were withdrawn from indwelling jugular catheters into heparinized tubes, centrifuged and the plasma stored at $-20^{\circ} \mathrm{C}$ until analysis. Frequent bleeding consisting of 36 samples taken every 20 min over $12 \mathrm{~h}$ was performed on the day of oestrus in the cyclic cows and 2 days after calving in the parturient cows. Further series of frequent bleedings were performed $1,4,11,18$ and 25 days after gonadectomy. Daily blood samples were taken on the intervening days; 3 samples were removed from each animal at 20 -min intervals. An additional series of frequent bleedings was carried out in 4 animals of each group 3-5 months after ovariectomy.

Hormone determinations. All samples were analysed radioimmunologically at least twice in duplicates of appropriate dilutions. LH was determined according to the method of Schams \& Karg (1969). The LH standard preparation (b-LH-DSA, prepared in our laboratory) had a potency of 1.0 times NIH-LH-S1; the antiserum to bovine $\mathrm{LH}$ was used in a dilution of 1:400 000. At least $0.25 \mathrm{ng} \mathrm{LH} / \mathrm{ml}$ could be detected. The inter-assay coefficient of variation was $18.8 \%$. The intra-assay coefficient of variation was $9.8 \%$. The FSH assay of Schams \& Schallenberger (1976) was slightly modified: the antiserum to ovine FSH was used in a dilution of 1:180 000. The FSH standard (NIH-FSH-B1) had a potency of 0.5 times NIH-FSH-S1. At least $17.5 \mathrm{ng} \mathrm{FSH} / \mathrm{ml}$ could be detected. The inter-assay coefficient of variation was $18.5 \%$; the intra-assay coefficient of variation was $11 \cdot 3 \%$.

Hormone data analysis. An LH pulse was defined as any value $>1$ s.d. above the 12-h mean and followed by at least 2 descending values. The time between two consecutive peaks was considered as the pulse interval. The amplitude was defined as the LH or FSH increase ( $\triangle \mathrm{LH}$ or $\Delta \mathrm{FSH}$ ) between the last (low) value before and the highest value during a pulse. Statistical significance of differences between means was evaluated by Student's $t$ test.

\section{Results}

\section{Cyclic cows}

Mean gonadotrophin concentrations increased significantly within $24 \mathrm{~h}$ after ovariectomy. Daily blood samples 2 and 3 days thereafter revealed a steady rise in LH and FSH concentrations such that at 4 days after ovariectomy the mean $\mathrm{LH}$ values were about 3 -fold and the mean FSH values about 2 -fold higher. The concentrations then plateaued around these levels for the remainder of the first experimental month (Text-fig. 1; Table 1). An example of the LH release pattern of an individual animal during the various occasions of frequent bleedings is given in Text-fig. 2(a).

The frequency and the amplitude of pulsatile LH release had increased 3-fold within the first 4 days after ovariectomy (Table 1). The frequency of pulsatile FSH secretion was identical to that of $\mathrm{LH}$, but the rise of the amplitude was much less pronounced. The amplitudes ( $\Delta \mathrm{LH}$ and $\triangle$ FSH) remained constant from Day 4 to Day 25, but had increased by Day 108, resulting in higher mean LH and FSH concentrations during the final experimental day. 

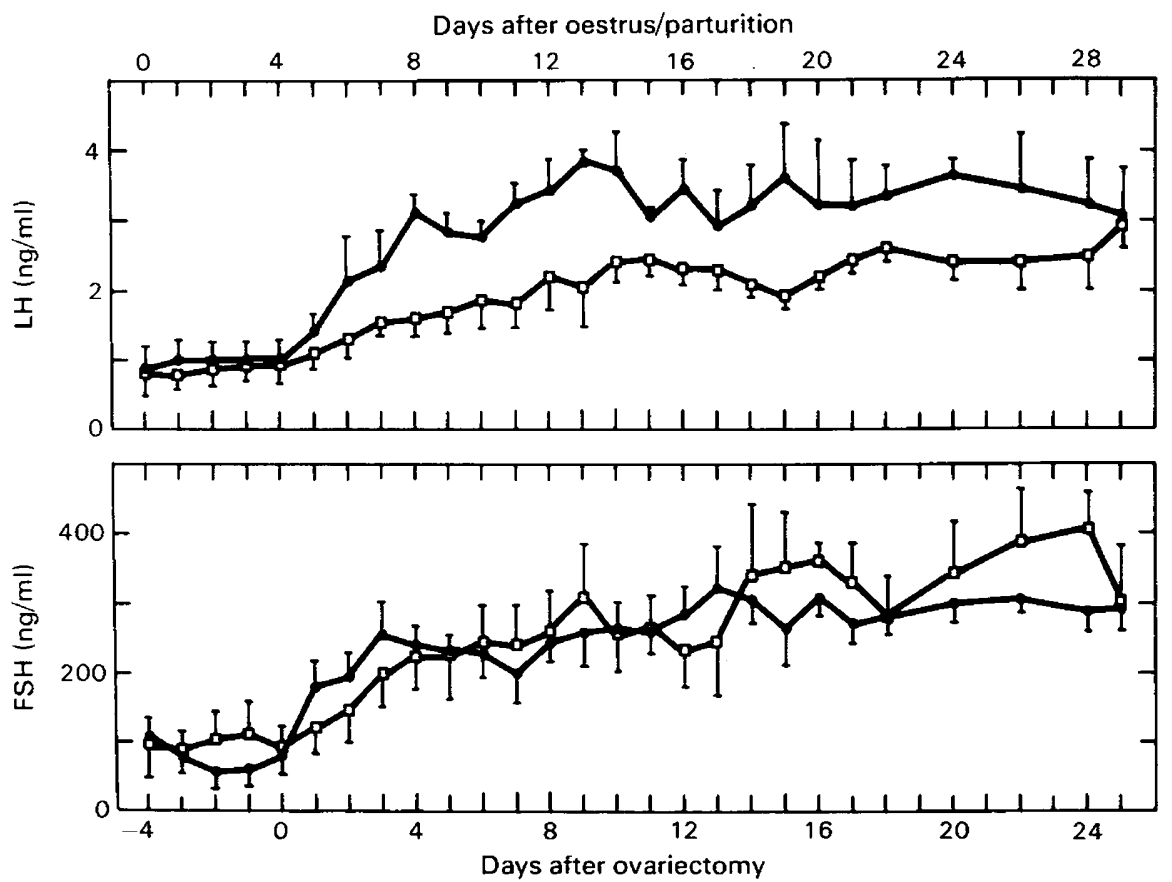

Text-fig. 1. Mean concentrations of LH and FSH in cows bilaterally ovariectomized on Day 4 of the oestrous cycle $(\Theta, N=5)$ or on Day 4 post partum $(\square, N=5)$ (see 'Materials and Methods' for frequency of blood sampling). Values are mean \pm s.e.m. for 36 samples during the intensive bleeding on Days -4 (cyclic), -2 (post-partum), 1, 4, 11, 18 and 25 , and for 3 pooled daily samples for each animal on the other days.

Table 1. Characteristics of gonadotrophin secretion in cows before and after ovariectomy performed on Day 4 of the oestrous cycle or on Day 4 after parturition

\begin{tabular}{|c|c|c|c|c|c|c|}
\hline $\begin{array}{c}\text { Days before/after } \\
\text { ovariectomy }\end{array}$ & $\begin{array}{l}\text { No. of } \\
\text { cows }\end{array}$ & $\begin{array}{c}\text { LH } \\
(\mathrm{ng} / \mathrm{ml})\end{array}$ & $\begin{array}{c}\text { FSH } \\
(\mathrm{ng} / \mathrm{ml})\end{array}$ & $\begin{array}{l}\text { Pulse interval } \\
\text { (min) }\end{array}$ & $\begin{array}{c}\text { Amplitude }(\Delta \mathrm{LH}) \\
(\mathrm{ng} / \mathrm{ml})\end{array}$ & $\begin{array}{c}\text { Amplitude }(\Delta \mathrm{FSH}) \\
(\mathrm{ng} / \mathrm{ml})\end{array}$ \\
\hline \multicolumn{7}{|l|}{ Cyclic cows } \\
\hline-4 & 5 & $0.9 \pm 0.2$ & $101 \pm 18$ & $207 \pm 53$ & $0.5 \pm 0.1$ & $45 \cdot 5 \pm 14 \cdot 3$ \\
\hline+1 & 5 & $1.4 \pm 0.2$ & $181 \pm 35$ & $96 \pm 6$ & $0.9 \pm 0.1$ & $67.2 \pm 13.6$ \\
\hline+4 & 5 & $3.1 \pm 0.2$ & $242 \pm 15$ & $73 \pm 2$ & $1.5 \pm 0.2$ & $65.6 \pm 6.0$ \\
\hline+11 & 5 & $3.0 \pm 0.1$ & $263 \pm 15$ & $73 \pm 5$ & $1.5 \pm 0.1$ & $57.8 \pm 11.3$ \\
\hline+18 & 5 & $3.3 \pm 0.4$ & $284 \pm 18$ & $94 \pm 7$ & $1.6 \pm 0.1$ & $69 \cdot 3 \pm 17.4$ \\
\hline+25 & 5 & $3.0 \pm 0.3$ & $288 \pm 30$ & $98 \pm 5$ & $1.6 \pm 0.2$ & $75 \cdot 6 \pm 27 \cdot 3$ \\
\hline+108 & 4 & $3.8 \pm 0.5$ & $357 \pm 62$ & $141 \pm 18$ & $2.8 \pm 0.3$ & $94.6 \pm 45.0$ \\
\hline \multicolumn{7}{|l|}{ Parturient cows } \\
\hline-2 & 5 & $0.8 \pm 0.1$ & $104 \pm 28$ & $231 \pm 9$ & $0.7 \pm 0.1$ & $52.8 \pm 9.3$ \\
\hline+1 & 5 & $1.1 \pm 0.2$ & $125 \pm 37$ & $161 \pm 6$ & $0.8 \pm 0.2$ & $61 \cdot 0 \pm 14 \cdot 0$ \\
\hline+4 & 5 & $1.6 \pm 0.2$ & $232 \pm 45$ & $113 \pm 17$ & $1.2 \pm 0.2$ & $80.7 \pm 18.9$ \\
\hline+11 & 5 & $2.4 \pm 0.3$ & $270 \pm 30$ & $78 \pm 8$ & $1.3 \pm 0.2$ & $87.6 \pm 20.3$ \\
\hline+18 & 5 & $2.6 \pm 0.2$ & $283 \pm 44$ & $78 \pm 3$ & $1.4 \pm 0.1$ & $108.0 \pm 33.9$ \\
\hline+25 & 5 & $2.9 \pm 0.3$ & $299 \pm 75$ & $81 \pm 3$ & $1.5 \pm 0.2$ & $96.3 \pm 16.2$ \\
\hline+128 & 4 & $3.9 \pm 0.3$ & $328 \pm 73$ & $121 \pm 6$ & $2.9 \pm 0.4$ & $114.8 \pm 19.7$ \\
\hline (range $96-147$ ) & & & & & & \\
\hline
\end{tabular}


(a) Cyclic cow

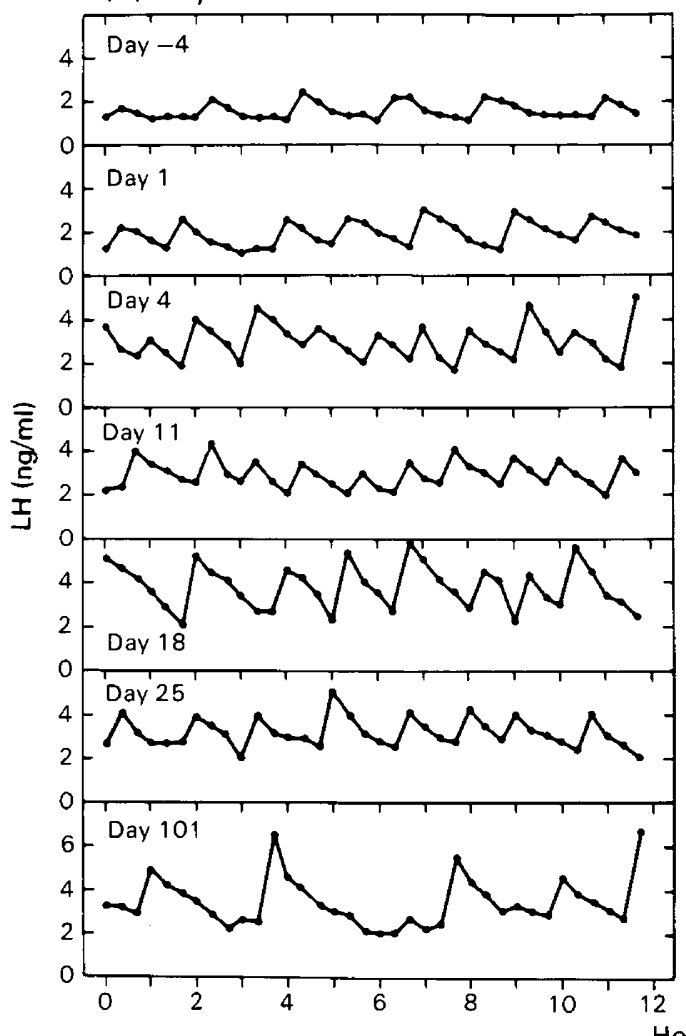

(b) Post-partum cow

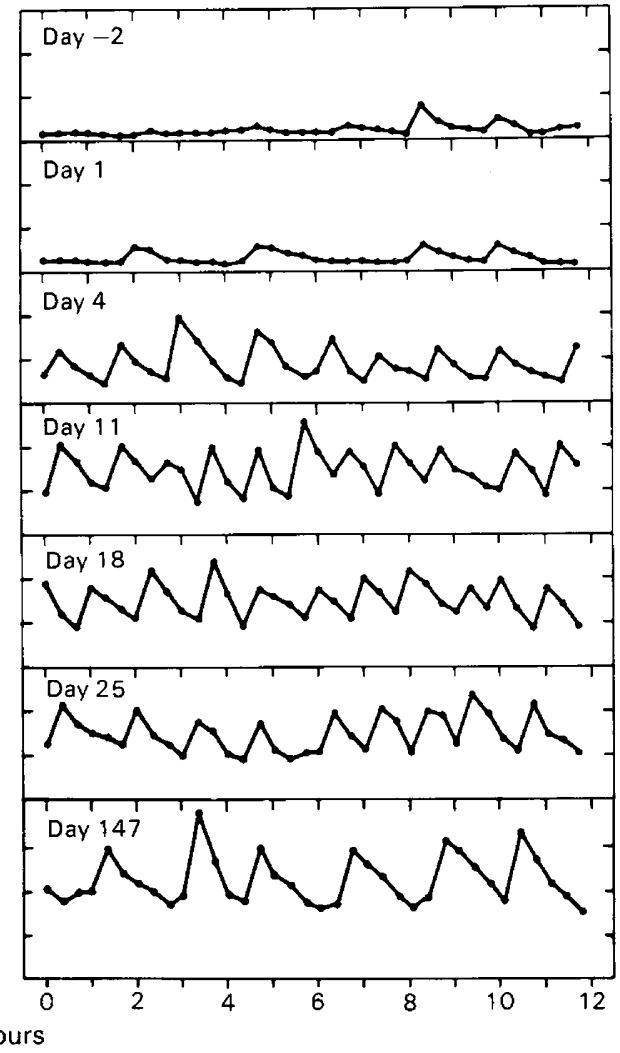

Text-fig. 2. Tonic LH secretion in a cow bilaterally ovariectomized (a) on Day 4 of the oestrous cycle and (b) on Day 4 post partum. Blood samples were taken every 20 min for $12 \mathrm{~h}$ on the days indicated (Day $0=$ ovariectomy).

\section{Post-partum cows}

The ovaries of all animals showed good follicular development at the time of surgery and 2 cows had recently ovulated. The frequency, amplitude and average LH secretion rose about 2-fold within the initial 4 days after ovariectomy (Text-fig. 1; Table 1). Average FSH secretion increased also about 2 -fold and was very similar to that of cyclic cows after ovariectomy. The rise in average LH and FSH concentrations was statistically significant by Day 4 after ovariectomy but not by Day 1. Pulse frequency, which was again identical for LH and FSH, was highest between Days 11-25 after ovariectomy (Days 15-29 post partum) and was reduced again during the last day of frequent bleedings when the amplitude was highest (Table 1). An example for the tonic LH secretion of an individual animal is given in Text-fig. 2(b).

\section{Discussion}

To our knowledge this is the first paper reporting frequency and amplitude changes of the tonic gonadotrophin release after ovariectomy of dairy cows. The rise in mean LH concentrations has been reported (Hobson \& Hansel, 1972; Convey, Beck, Neitzel, Bostwick \& Hafs, 1977). The LH secretion characteristics during the series of frequent blood samplings before ovariectomy agree well with those published for cyclic cows by Rahe, Owens, Fleeger, Newton \& Harms 
(1980). All animals in our study responded with a biphasic gonadotrophin rise: there was an initial 2- or 3-fold acceleration of the frequency and augmentation of the amplitude of pulsatile release and then a reduction of frequency concomitant with a substantial rise of the amplitude. The average gonadotrophin values by 4-11 days after ovariectomy consisted of relatively frequent but small pulses, whereas by 3-5 months the pulses were less frequent, but of greater magnitude, leading to further enhanced average levels. This reversal of the pulse frequency and amplitude as the time from gonadectomy progresses indicates that there are controlling mechanisms, independent of the negative feedback influence of gonadal steroids, which finally balance the secretion rate of gonadotrophins. The prompt rise in pituitary or serum LH and FSH that normally follows ovariectomy is abolished in post-partum nursing females of various species (Crighton \& Lamming, 1969; Parvizi, Elsaesser, Smidt \& Ellendorff, 1976; Weiss, Butler, Dierschke \& Knobil, 1976; Smith \& Neill, 1977), demonstrating that the strong suckling stimuli can override the negative feedback control of gonadal steroids. A blockade superimposing hypothalamic function after parturition is also implied because oestrogen administration fails to elicit an LH response soon after parturition in suckling sows (Elsaesser \& Parvizi, 1980), beef cows (Radford et al., 1978) and dairy cows suckling several calves (Smith et al., 1981). Hypothalamic mechanisms responsible for the pulsatile release of gonadotrophin-releasing hormone (Carmal, Araki \& Ferin, 1976; Belchetz, Plant, Nakai, Keogh \& Knobil, 1978) may be inhibited or at least slowed down. The similarity of the rises of FSH and of LH secretion in the cows of the present study may provide some insight into the mode of this inhibition: the slower acceleration in the frequency of discontinuous gonadotrophin secretion might reflect a gradual acceleration in the frequency of pulsatile $\mathrm{GnRH}$ release stimulating the pituitary gland. Studies of primates (Knobil, 1980; Plant et al., 1980) suggest that the frequency of pulsatile GnRH stimulation plays a key role in determining the $\mathrm{LH}$ : FSH ratio in the peripheral circulation.

The findings of the present study indicate that the hypothalamo-pituitary axis of the post-partum dairy cow is not completely refractory to the opening of the negative feedback-loop after the withdrawal of ovarian steroids and that this gradually changing refractoriness is overcome within 14 days after calving, causing most probably an acceleration of discontinuous GnRH secretion modulating LH and FSH secretion from the pituitary gland. The observations reported by others agree with this contention: basal concentrations of LH increase in dairy cows post partum and reach values seen during the luteal phase of the cycle 10-20 days after calving (Schams et al., 1978; Rawlings, Weir, Todd, Manns \& Hyland, 1980; Webb et al., 1980). Furthermore the $\mathrm{LH}$ response to $\mathrm{GnRH}$ administration, after a nadir around calving, returns to that seen during the oestrous cycle within the same time period (Lamming, 1978; Schallenberger et al., 1978), whereas the FSH response never exhibits this sharp suppression around parturition (Schallenberger et al., 1978).

The FSH reference preparation (NIH-FSH-B1) was kindly supplied by the National Institutes of Health, Bethesda, U.S.A. The skilful assistance of Ms Schmidt-Erhard and $\mathrm{Mr}$ Prokopp and of our animal care staff is greatly appreciated. This project was supported by the Deutsche Forschungsgemeinschaft. A.J.P. was an Alexander von Humboldt Research Fellow.

\section{References}

Belchetz, P.E., Plant, T.M., Nakai, Y., Keogh, E.J. \& Knobil, E. (1978) Hypophyseal responses to continuous and intermittent delivery of hypothalamic gonadotropin-releasing hormone. Science, N.Y. 202, $631-633$.

Carmal, P.W., Araki, S. \& Ferin, M. (1976) Pituitary stalk portal blood collection in rhesus monkeys: evidence for pulsatile release of gonadotropin- releasing hormone (GnRH). Endocrinology 99, 243-248.

Carruthers, T.D. \& Hafs, H.D. (1980) Suckling and four-times daily milking: influence on ovulation, estrus and serum luteinizing hormone, glucocorticoids and prolactin in postpartum Holsteins. $J$. Anim. Sci. 50, 919-925.

Convey, E.M., Beck, T.W., Neitzel, R.R., Bostwick, E.F. 
\& Hafs, H.D. (1977) Negative feedback control of bovine serum luteinizing hormone (LH) concentration from completion of the preovulatory $\mathrm{LH}$ surge until resumption of luteal function. J. Anim. Sci. 46, 729-796.

Crighton, D.B. \& Lamming, G.E. (1969) The lactational anoestrus of the sow: the status of the anterior pituitary-ovarian system during lactation and after weaning. J. Endocr. 43, 507-519.

Elsaesser, F. \& Parvizi, N. (1980) Partial recovery of the stimulatory oestrogen feedback action on $\mathrm{LH}$ release during late lactation in the pig. J. Reprod. Fert. 59, 63-67.

Hobson, W.C. \& Hansel, W. (1972) Plasma LH levels after ovariectomy, corpus luteum removal and estradiol administration in cattle. Endocrinology 91, 185-190.

King, G.J., Hurnik, J.F. \& Robertson, H.A. (1976) Ovarian function and estrus in dairy cows during early lactation. J. Anim. Sci. 42, 688-692.

Knobil, E. (1980) Neuroendocrine control of the menstrual cycle. Recent Prog. Horm. Res. 36, 53-88.

Lamming, G.E. (1978) Reproduction during lactation. In Control of Ovulation, pp. 335-353. Eds D. B. Crighton, N.B. Haynes, G. R. Foxcroft \& G. E. Lamming. Butterworths, London.

Parvizi, N., Elsaesser, F., Smidt, D. \& Ellendorff, F. (1976) Plasma luteinizing hormone and progesterone in the adult female pig during the oestrous cycle, late pregnancy and lactation, and after ovariectomy and pentobarbitone treatment. J. Endocr. 69, 193-203.

Plant, T.M., Schallenberger, E., Hess, D.L., McCormack, J.T., Dufy-Barbe, L. \& Knobil, E. (1980) The influence of suckling on gonadotropin secretion in the female rhesus monkey (Macaca mulatta). Biol. Reprod. 23, 760-766.

Radford, H.M., Nancarrow, C.D. \& Mattner, P.E. (1978) Ovarian function in suckling and nonsuckling beef cows post-partum. J. Reprod. Fert. 54, 49-56.

Rahe, C.H., Owens, R.E., Fleeger, J.L., Newton, H.J. \& Harms, P.G. (1980) Pattern of plasma luteinizing hormone in the cyclic cow: dependence upon the period of the cycle. Endocrinology 107, 498-503.

Rawlings, N.C., Weir, L., Todd, B., Manns, J. \& Hyland, J.H. (1980) Some endocrine changes associated with the post-partum period of the suckling beef cow. $J$. Reprod. Fert. 60, 301-308.

Schallenberger, E., Schams, D. \& Zottmeier, K. (1978) Response of lutropin ( $\mathrm{LH})$ and follitropin (FSH) to the administration of gonadoliberin (GnRH) in pregnant and post-partum cattle including experiments with prolactin suppression. Theriogenology 10 , 35-53.

Schams, D. \& Karg, H. (1969) Radioimmunologische LH-Bestimmung im Blutserum vom Rind unter besonderer Berücksichtigung des Brunstzyklus. Acta endocr., Copenh. 61, 96-103.

Schams, D. \& Schallenberger, E. (1976) Heterologous radioimmunoassay for bovine follicle-stimulating hormone and its application during the oestrous cycle in cattle. Acta endocr., Copenh. 81, 461-473.

Schams, D., Schallenberger, E., Menzer, Ch., Stangl, J., Zottmeier, K., Hoffmann, B. \& Karg, H. (1978) Profiles of LH, FSH and progesterone in postpartum dairy cows and their relationships to commencement of cyclic functions. Theriogenology 10, 453-468.

Smith, J.F., Payne, E., Tervit, H.R., MeGowan, L.T., Fairclough, R., Kilgour, R. \& Goold, P.G. (1981) The effect of suckling upon the endocrine changes associated with anoestrus in identical twin dairy cows. J. Reprod. Fert., Suppl. 30, 241-249.

Smith, M.S. \& Neill, J.D. (1977) Inhibition of gonadotropin secretion during lactation in the rat: relative contribution of suckling and ovarian steroids. Biol. Reprod. 17, 255-261.

Walters, D.L., Kaltenbach, C.C., Dunn, T.G. \& Short, R.E. (1981a) Pituitary and ovarian function in post partum beef cows. I. Effect of weaning on serum and follicular fluid hormones and follicular gonadotropin receptors. Biol. Reprod. (in press).

Walters, D.L., Short, R.E., Convey, E.M., Staigmiller, R.B., Dunn, T.G. \& Kaltenbach, C.C. (1981b) Pituitary and ovarian function in postpartum beef cows. II. Effect of duration of weaning on pituitary responsiveness in vitro to $\mathrm{GnRH}$, and on serum, follicular fluid and pituitary hormones and follicular gonadotropin receptors. Biol. Reprod. (in press).

Webb, R., Lamming, G.E., Haynes, N.B., Hafs, H.D. \& Manns, J.G. (1977) Response of cyclic and postpartum suckled cows to injections of synthetic LH-RH. J. Reprod. Fert. 50, 203-210.

Webb, R., Lamming, G.E., Haynes, N.B. \& Foxcroft, G.R. (1980) Plasma progesterone and gonadotrophin concentrations and ovarian activity in postpartum dairy cows. J. Reprod. Fert. 59, 133-143.

Weiss, G., Butler, W.R., Dierschke, D.J. \& Knobil, E. (1976) Influence of suckling on gonadotropin secretion in the post partum rhesus monkey. Proc. Soc. exp. Biol. Med. 153, 330-331. 